\title{
Evaluation of changes in the concentrations of selected acute phase proteins after tooth socket augmentation with the R.T.R. bone grafting material
}

\author{
Ocena stężeń wybranych białek ostrej fazy po zabiegu augmentacji \\ zębodołu materiałem kościozastępczym R.T.R.
}

\author{
Department of Dental Surgery, Poznan University of Medical Sciences, Poland
}

DOI: http://dx.doi.org/10.20883/df.2017.16

\begin{abstract}
Introduction. Socket augmentation with synthetic biomaterials performed immediately after tooth extraction significantly reduces the resorption of the alveolar process whose adequate quality and quantity allows the use of intraosseous implants for rehabilitation of the masticatory system. Implanting synthetic bone grafting material into the human body may cause homeostasis disorders which are manifested by changes in the concentrations of the constituent components of plasma referred to as acute phase proteins (APP).

Aim. The study attempted to evaluate the quantitative changes of acute phase proteins following tooth extraction and tooth socket augmentation with the RTR bone grafting material Septodont.

Material and Methods. Forty patients of both sexes, aged 22 to 56, entered the study. Their average age was 32 . The qualifying criteria for patients to enter the study were the presence of a tooth to be extracted and good general health. Tooth extraction and the application of the RTR bone grafting material into the socket was performed under local anaesthesia. The evaluation of selected acute phase protein concentrations was performed by rocket immunoelectrophoresis according to Laurell. The concentrations of the $\mathrm{C}$ - reactive (CRP), $\alpha 2-$ macroglobulin (L2M), $\alpha 1-$ antitrypsin (AT), transferring (Tf), ceruloplasmin (Cp) and haptoglobin (Hp) proteins were evaluated.

Results. The results obtained suggest that the qualitative and quantitative evaluation of acute phase proteins may be useful for monitoring inflammatory complications following tooth extraction and tooth socket augmentation with RTR bone grafting material.

Conclusions. Based on the results obtained the authors concluded that single tooth extraction and tooth socket augmentation pose a minor trauma to a body, which was shown by slight concentration changes of acute phase proteins. The most visible changes in the concentrations were obtained for the C-reactive protein. Significant differences in CRP concentrations, beyond the norm, occurred in cases of complications: submucosal abscesses and the resorption of implanted material.
\end{abstract}

Keywords: acute phase proteins, tooth extraction, augmentation, biomaterials.

\section{Streszczenie}

Wstęp. Augmentacja zębodołu bezpośrednio po ekstrakcji zęba z użyciem syntetycznych biomateriałów znacznie ogranicza resorpcję kości wyrostka zębodołowego, którego adekwatna ilość i jakość pozwala na zastosowanie wszczepów śródkostnych w rehabilitacji narządu żucia. Wszczepienie do organizmu człowieka syntetycznego substytutu kości może stanowić przyczynę zachwiania homeostazy, manifestującego się zmianami stężeń konstytutywnych składników osocza, zwanych białkami ostrej fazy (bof).

Cel. W badaniu autorzy podjęli próbę oceny zmian ilościowych białek ostrej fazy po zabiegu ekstrakcji zęba i augmentacji zębodołu materiałem kościozastępczym R.T.R. firmy Septodont.

Materiał i metody. Badaniem objęto 40 pacjentów obojga płci w wieku od 22 do 56 roku życia. Średnia wieku wynosiła 32 lata. Kryterium kwalifikacji pacjenta do badania była obecność zęba ze wskazaniem do jego ekstrakcji oraz dobry ogólny stan zdrowia. Zabieg usunięcia zęba i aplikacji materiału kościozastępczego R.T.R. do zębodołu przeprowadzano w znieczuleniu miejscowym. Oznaczenie stężenia wybranych białek ostrej fazy wykonywano przy użyciu immunoelektroforezy rakietkowej według Laurella. Oceniono stężenie następujących białek: CRP, AT, Cp, Hp, Tf i L2M.

Wyniki. Otrzymane wyniki sugerują, iż ocena ilościowa i jakościowa białek ostrej fazy może być przydatna w przypadku monitorowania pojawienia się powikłań o charakterze zapalnym po zabiegu ekstrakcji i augmentacji zębodołu materiałem R.T.R.

Wnioski. Na podstawie uzyskanych wyników badań można wnioskować, iż pojedyncza ekstrakcja zęba i augmentacja zębodołu stanowią niewielki uraz dla ustroju, czego dowodem były nieznaczne zmiany w stężeniach białek ostrej fazy. Najbardziej wyraźne zmiany stężeń uzyskano dla białka C-reaktywnego. Zdecydowane różnice stężenia CRP (przekraczające granicę normy) uzyskano w przypadku powikłań: ropnia podśluzówkowego oraz resorpcji wszczepionego materiału.

Słowa kluczowe: białka ostrej fazy, ekstrakcja, augmentacja, biomateriały. 


\section{Introduction}

The application of intraosseous implants to restore missing teeth is a standard modern dental treatment. To comply with this standard dentists are required to retain the maximum volume of alveolar bone after tooth extraction. The literature in English refers to such treatment as "socket preservation", and defines it as the implantation of bone grafting materials into the socket immediately after extraction. The wide spectrum of augmentative needs persuaded the authors to determine if the applied biomaterials may lead to a systemic inflammatory reaction.

A healthy human body maintains a regulatory balance called homeostasis with the proper concentration of plasma proteins, called acute phase proteins, being one of its indicators. Changes in these concentrations can be the result of bacterial infections as well as physical, chemical and mechanical injuries, including postoperative injuries, and they constitute a nonspecific laboratory marker of existing and active inflammation. As a result of a damaging agent, interleukin- 6 group cytokines increase the synthesis of acute phase proteins in the liver [1-3]. Thanks to this mechanism a reduction in the inflammatory reaction occurs and reparatory processes are initiated. Acute phase proteins have a wide spectrum of functions: they are responsible for chemotaxy, granulocyte and monocyte opsonisation, and they increase phagocytosis as well as resorption and regeneration of damaged tissues [4]. They also deactivate protheolitic enzymes, transport ions and inhibit the loss of such important elements as iron, copper and zinc $[4,5]$.

There are many classifications of acute phase proteins in the literature. One of them divides proteins into positive ones, the plasma concentrations which increase by no more than $25 \%$; and negative ones, which decrease their concentrations as a result of a damaging agent [7]. Kushner divides proteins according to the differences in the increase of their concentrations: proteins whose concentrations increase by ca. $50 \%$ (celuroplasmine - Cp, C3), proteins whose concentrations increase 2-4 times ( $\alpha 1$ - acid glicoprotein - AGP, $\alpha 1$ - antitrypsin - AT, antichymotrypsin - ACT, fibrinogen, haptoglobin), and proteins whose concentrations increase ca. 1000 times (C-reactive protein CRP, SAA) [8]. Another classification is related to the speed of protein concentration increase. There are first line proteins, whose concentrations increase 6-8 hours after the activation of a damaging agent, and second line proteins, whose concentrations increase within a $24-48$ hour period. The first line protein concentrations reach their maximum values after 24-48 hours. Their normal values are restored $4-5$ days after the damaging agent is eliminated. They include: CRP SAA, ACT. The highest concentrations of second line proteins occur after 72-96 hours. Normal values return no earlier than 10 days after the negative agent is eliminated, and complete normalisation may take as long as a few weeks $[8,9]$.

The CRP serum concentration level test is performed as a standard laboratory test for patients suspected of infection. Significant growth in the CRP serum concentration level is related to bacterial and viral infections [2, 10-13]. This test is also a useful indicator of a successful antibiotic therapy.

Monitoring of APP concentrations has become a useful diagnostic marker in the treatment of postoperative infections, burn wounds, neoplastic diseases, metabolic syndrome, diabetes, rheumatoid arthritis and uncomplicated pregnancy $[3,4$, 14-16].

In the mouth the CRP concentration values are used in the treatment of patients with odontogenic abscesses [17]. Fluctuations in the CRP level were also observed in aggressive periodontitis, aphthous ulcerations and Behçet syndrome [18, 19]. An increase in the CRP concentration and a decrease in the Tf concentration have been observed after oral surgeries, the placing of titanium implants and the surgical removal of wisdom teeth [20]. A reduction in the CRP level has been observed as a result of anti-inflammatory laser radiation after the removal of an impacted third molar [2].

Moreover, implantation of biomaterials brought about quantitative changes, especially of CRP and AGP. So far, tests related to coronary stents application, hip replacements, and biodegradable polymers to restore defects of the gastrointestinal duct walls have been described [2, 22-26].

In a study of the available literature the results of acute phase protein concentrations after placing maxillary and mandibular dental implants can also be found [20].

Aim

The aim of the study was to analyse changes in the concentrations of selected acute phase proteins after tooth socket augmentation with the RTR material immediately after tooth extraction.

\section{Material and methods}

The study was performed in patients after tooth extraction where it was planned to have their tooth sockets augmented with a bone grafting material to provide a bony bed for implant treatment scheduled at a later date. Indications for tooth removal 
were identified as: root canal treatment failure -18 cases, crown loss below alveolar process margin - 13 cases, root caries - 4 cases, floor chamber perforation -3 cases, diagonal root fracture -2 cases. To qualify for the procedure the patients had to be in good general health, had neither local nor systemic inflammations, were not taking any medications, were referred for tooth extraction, and had no clinical or radiological symptoms of inflammation. Consent for the study was obtained from the Regional Committee on Bioethics of the Poznan University of Medical Sciences. The patients were informed about the benefits and possible postoperative complications; they also gave their written consent to participate in the study, and to have their blood samples taken. The procedures were performed at the Chair and Clinic of Oral Surgery of the Poznan University of Medical Sciences.

The study included forty patients: 23 women and 17 men, aged 22 to 56 . Their average age was 32. Tooth extractions were performed in an atraumatic mode under local anaesthesia. For augmentation, the RTR bone grafting material Septodont in the form of granules or cones was used. The RTR material is a synthetic calcium triphosphate (Ca3(PO4)2). The cones are also made of calcium triphosphate granules additionally coated with a matrix of high purity bovine collagen fibres. The choice of the RTR material used was done randomly. The socket was filled tightly with the material, avoiding condensation, according to the manufacturer's instructions. The wound was sealed tightly with Daphilon 5.0 sutures which were removed seven days after surgery. An antibiotic course was prescribed due to foreign-body (the augmentation material) implantation. The treatment was carried out using Clindamycin $600 \mathrm{mg}$ as the antibiotic at a dose of one capsule two times daily. To relieve possible postoperative pain Ketonal Forte $100 \mathrm{mg}$ was prescribed to the patients. After surgery, the patients were recommended to use cold packs and to rinse the mouth with chlorhexidine solution.

Postoperative follow-ups and the collection of material for laboratory tests were performed after 24 hours and after 7 days following surgery. Blood was collected three times: immediately before the surgery, 24 hours later, and 7 days after the surgery. Each time ca. $3 \mathrm{ml}$ of peripheral blood was collected from the antecubital vein. Blood samples were centrifuged for 10 minutes at $1500 \mathrm{rpm}$, and the obtained serum was frozen at -20 degrees Celsius. After unfreezing, the concentrations of the following acute phase proteins were studied by rocket immunoelectrophoresis according to Laurell: $\mathrm{C}$ - reactive protein, $\alpha 2$ - macroglobulin, a 1 - antitrypsin, transferrin, ceruloplasmin, and haptoglobin.

The results were statistically analysed using the following tests: Shapiro-Wilk, Friedman's with Dunn contrast analysis, ANNOVA with Statistica. pl v 9.1 software, and Instat v 3.00 Graphpad software. A significance level of $p<0.05$ was assumed as the statistically significant value.

\section{Results}

In the studied group of patients a total of forty teeth were extracted, including 24 maxillary and 16 mandibular teeth. The healing of postoperative wounds after implanting the bone grafting material was uneventful. Within 2-3 days after implantation of the RTR material only a slight swelling of the surrounding soft tissue was observed proportional to the extent of their preparation. At the follow-up visit one week after the procedure no reddening, soft tissue swelling or spontaneous pain was observed.

Twenty four hours after treatment wound edge dehiscence was observed in only two patients, and a similar complication was observed in 3 more patients 7 days after treatment. Sequestration of single granules of the preparation due to wound edge dehiscence was observed in 3 patients who received the bone grafting material as granules. The treatment consisted of washing the wound with a solution of potassium permanganate. In patients with the bone grafting material as cones, no sequestration of the material was observed. In one patient a buccal abscess was observed on the second day after surgery, which was treated with incision and drainage, according to standard rules.

A sensation disorder of the upper lip was found in one female patient. Regeneration of the damaged sensory nerve endings was assisted by Sollux lamp irradiation with a blue filter, and by galvanisation. Over time, a gradual restoration of the lost nerve function was observed.

\section{Concentration changes in selected acute phase proteins}

\subsection{C-reactive protein (CRP)}

The average concentration of C-reactive protein before tooth extraction and the resulting tooth socket augmentation with the RTR bone grafting material was $0.23 \mathrm{mg} / \mathrm{l} \pm 0.83 \mathrm{mg} / \mathrm{l}$. Twenty four hours after surgery the average concentration of CRP remained at a similar level and amounted to $0.18 \mathrm{mg} / \mathrm{l} \pm 0.78 \mathrm{mg} / \mathrm{l}$. One week after surgery the average concentration of CRP increased to 0.43 $\mathrm{mg} / \mathrm{l} \pm 2.38 \mathrm{mg} / \mathrm{l}$. Differences in the measured concentrations were statistically insignificant and within the norm. In the third measurement perfor- 


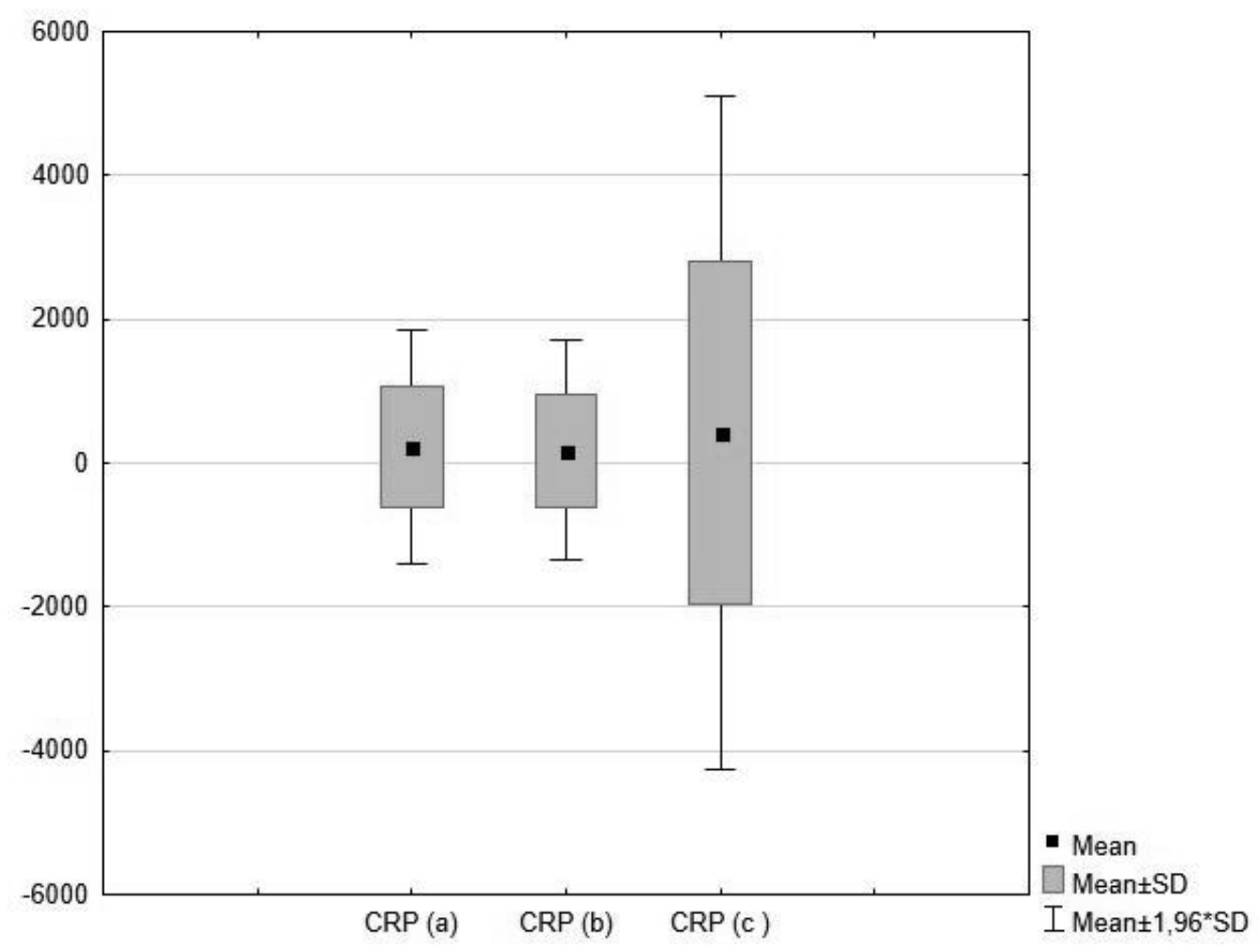

Figure 1. CRP concentrations from three consecutive measurements $(a, b, c)$

Rycina 1. Stężenia CRP z trzech kolejnych pomiarów $(a, b, c)$

med one week after surgery a few high values of CRP which exceeded the accepted norm were recorded (Figure 1).

\section{2. $\alpha 2$ - macroglobulin (L2M)}

The average concentration of $\alpha 2$ - macroglobulin before surgery was $1.35 \mathrm{~g} / \mathrm{l} \pm 1.87 \mathrm{~g} / \mathrm{l}$ and was below the lower range limit (1.5-4 g/l). Twenty four hours after surgery the average concentration decreased to $1.32 \mathrm{~g} / \mathrm{l} \pm 1.78 \mathrm{~g} / \mathrm{l}$, and 7 days after treatment the average concentration of the tested protein decreased to $1.27 \mathrm{~g} / \mathrm{l} \pm 2.02 \mathrm{~g} / \mathrm{l}$.

The differences in concentrations obtained from the three consecutive measurements were statistically insignificant (Figure 2).

\section{3. a 1 - antitrypsin (AT)}

The average concentration of $\alpha 1-$ antitrypsin before treatment was within the norm (1.9-3.5 g/l) and was $2.30 \mathrm{~g} / \mathrm{l} \pm 0.7 \mathrm{~g} / \mathrm{l}$. Twenty four hours after treatment the average concentration increased slightly to $2.55 \mathrm{~g} / \mathrm{l} \pm 0.8 \mathrm{~g} / \mathrm{l}$. One week after surgery, the average AT concentration maintained an upward trend and amounted to $2.64 \mathrm{~g} / \mathrm{l} \pm 0.8 \mathrm{~g} / \mathrm{l}$. The results of the second and third measurements remained within the norm, too.

The differences in the average concentrations of $\alpha 1-$ antitrypsin in the first and third measure- ments were statistically significant $(p<0.01)$ (Figure 3).

\subsection{Transferrin (Tf)}

The average serum concentration of transferrin in patients before treatment was within the norm $(2.2-3.7 \mathrm{~g} / \mathrm{l})$ and amounted to $3.15 \mathrm{~g} / \mathrm{l} \pm 0.14 \mathrm{~g} / \mathrm{l}$. Twenty-four hours after surgery the average concentration decreased to $2.88 \mathrm{~g} / \mathrm{l} \pm 0.13 \mathrm{~g} / \mathrm{l}$. A week after treatment the average concentration increased to $3.08 \mathrm{~g} / \mathrm{l} \pm 0.16 \mathrm{~g} / \mathrm{l}$.

The differences in the average concentrations of transferrin in the three consecutive measurements were not statistically significant (Figure 4).

\subsection{Ceruloplasmin (Cp)}

In all patients before tooth extraction and tooth socket augmentation with the RTR bone grafting material the average blood plasma concentration of ceruloplasmin was within the norm (380-500 $\mathrm{mg} / \mathrm{l})$ and was $419 \mathrm{mg} / \mathrm{l} \pm 177 \mathrm{mg} / \mathrm{l}$. After 24 hours the average concentration slightly increased to $440 \mathrm{mg} / \mathrm{l} \pm 170 \mathrm{mg} / \mathrm{l}$. One week after surgery a further increase in the average concentration was noted and amounted to $505 \mathrm{mg} / \mathrm{l} \pm 220 \mathrm{mg} / \mathrm{l}$, slightly exceeding the upper normal limit.

The average concentration of ceruloplasmin achieved in the first and third measurement, taken 


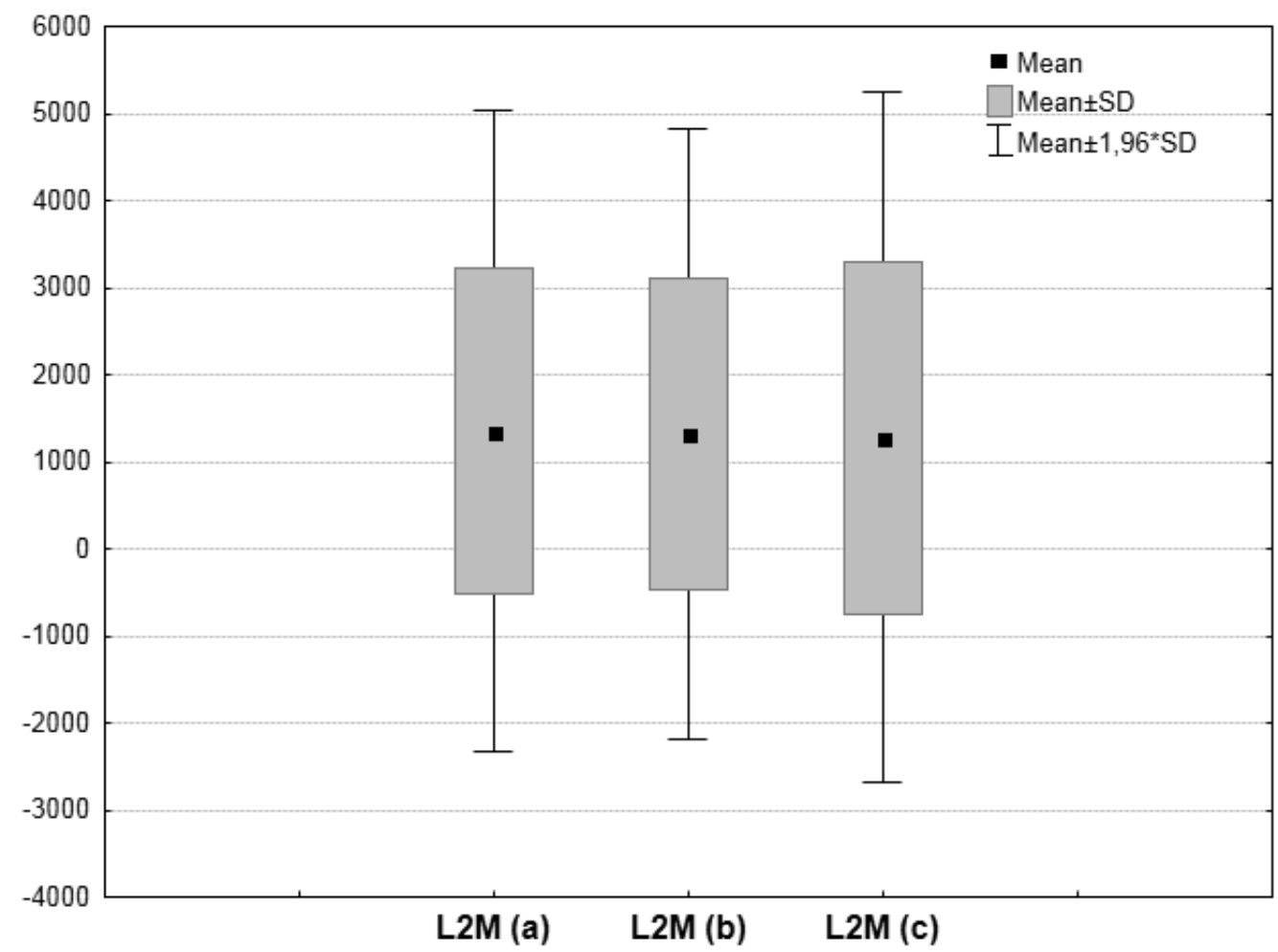

Figure 2. L2M concentrations in three consecutive measurements (a, b, c)

Rycina 2. Stężenie L2M z trzech kolejnych pomiarów $(a, b, c)$

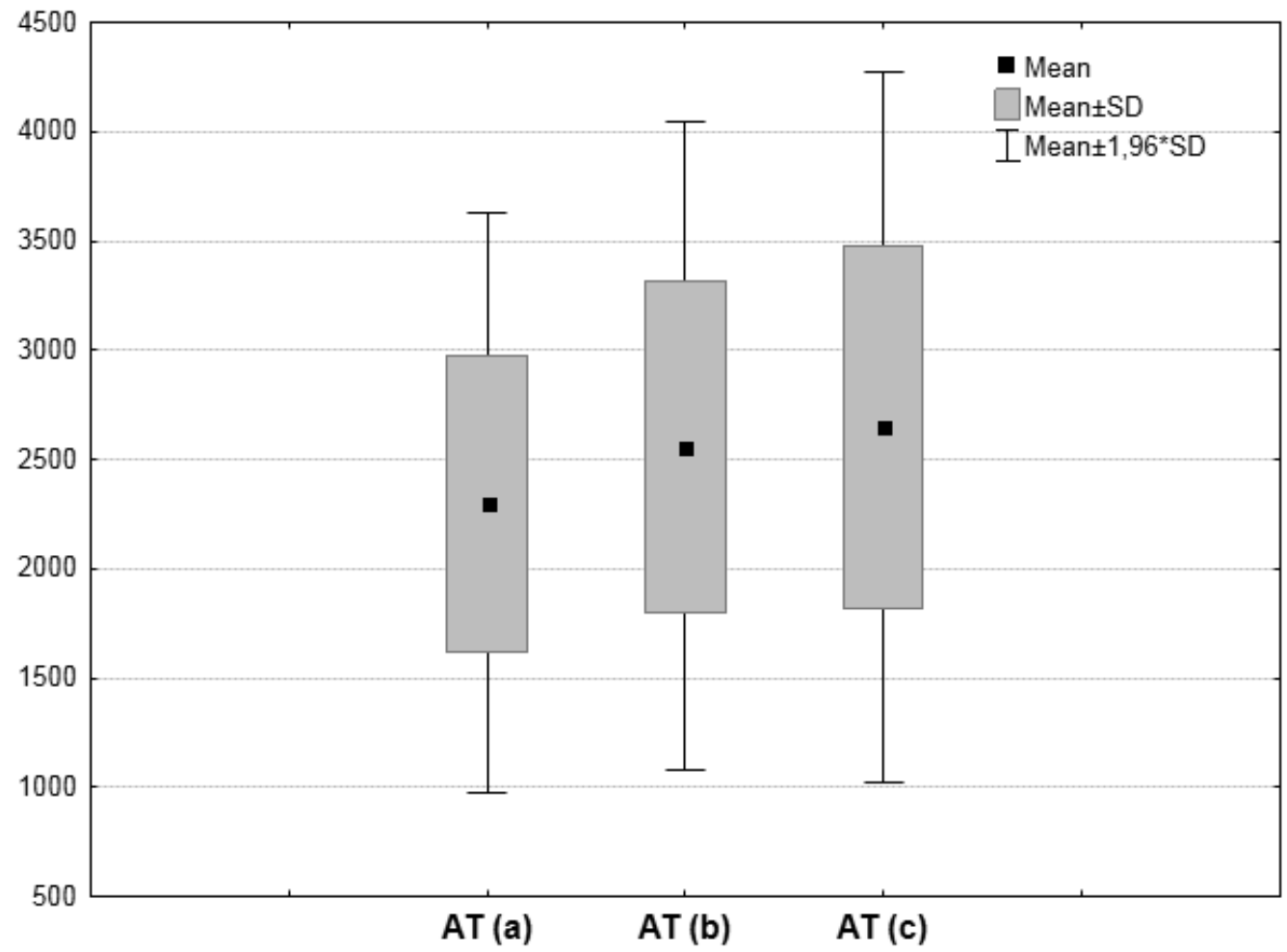

Figure 3. AT concentrations in three consecutive measurements (a, b, c)

Rycina 3. Stężenia AT z trzech kolejnych pomiarów (a, b, c) 


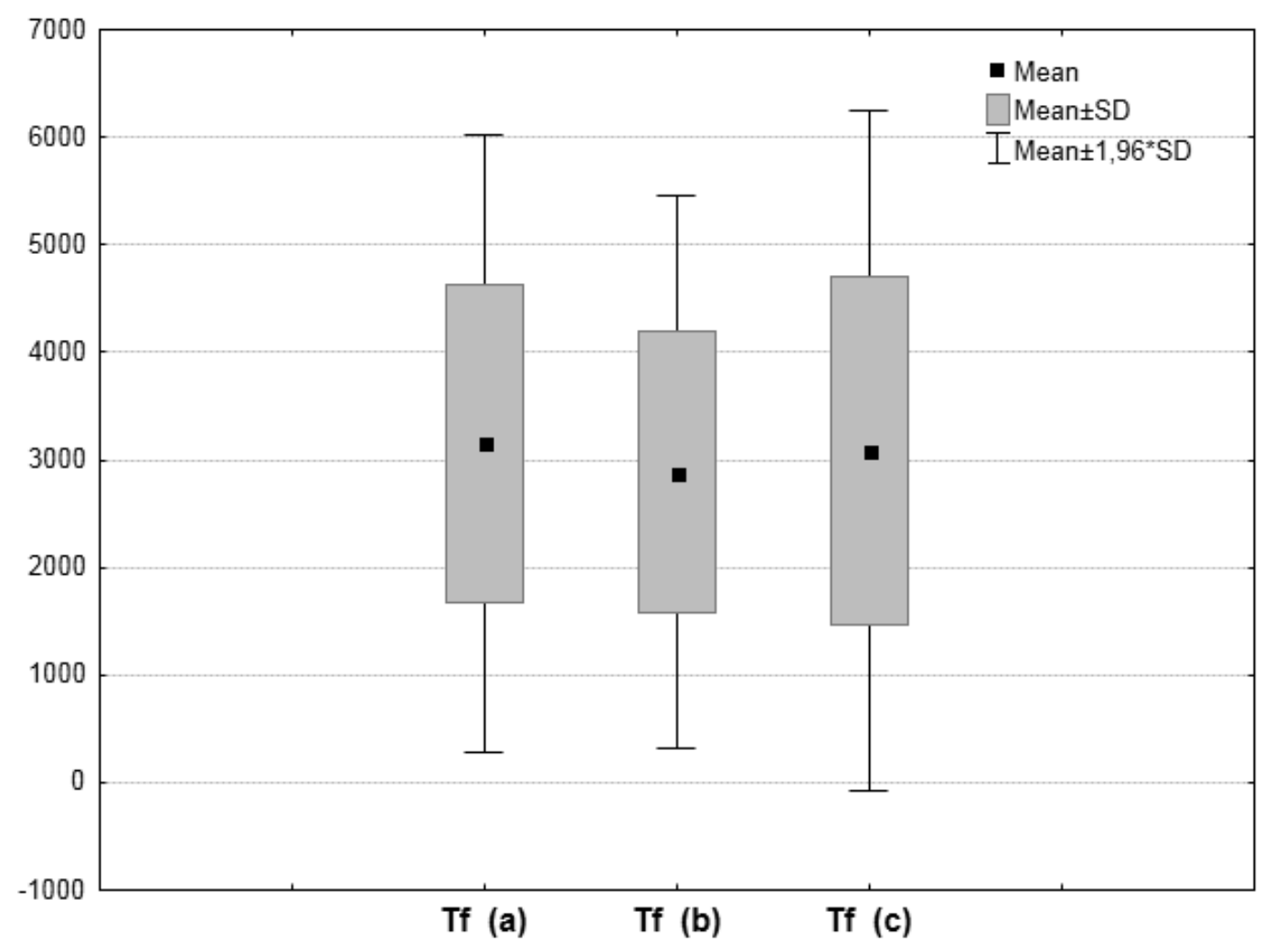

Figure 4. Tf concentrations in three consecutive measurements (a, b, c)

Rycina 4. Stężenia Tf z trzech kolejnych pomiarów $(a, b, c)$

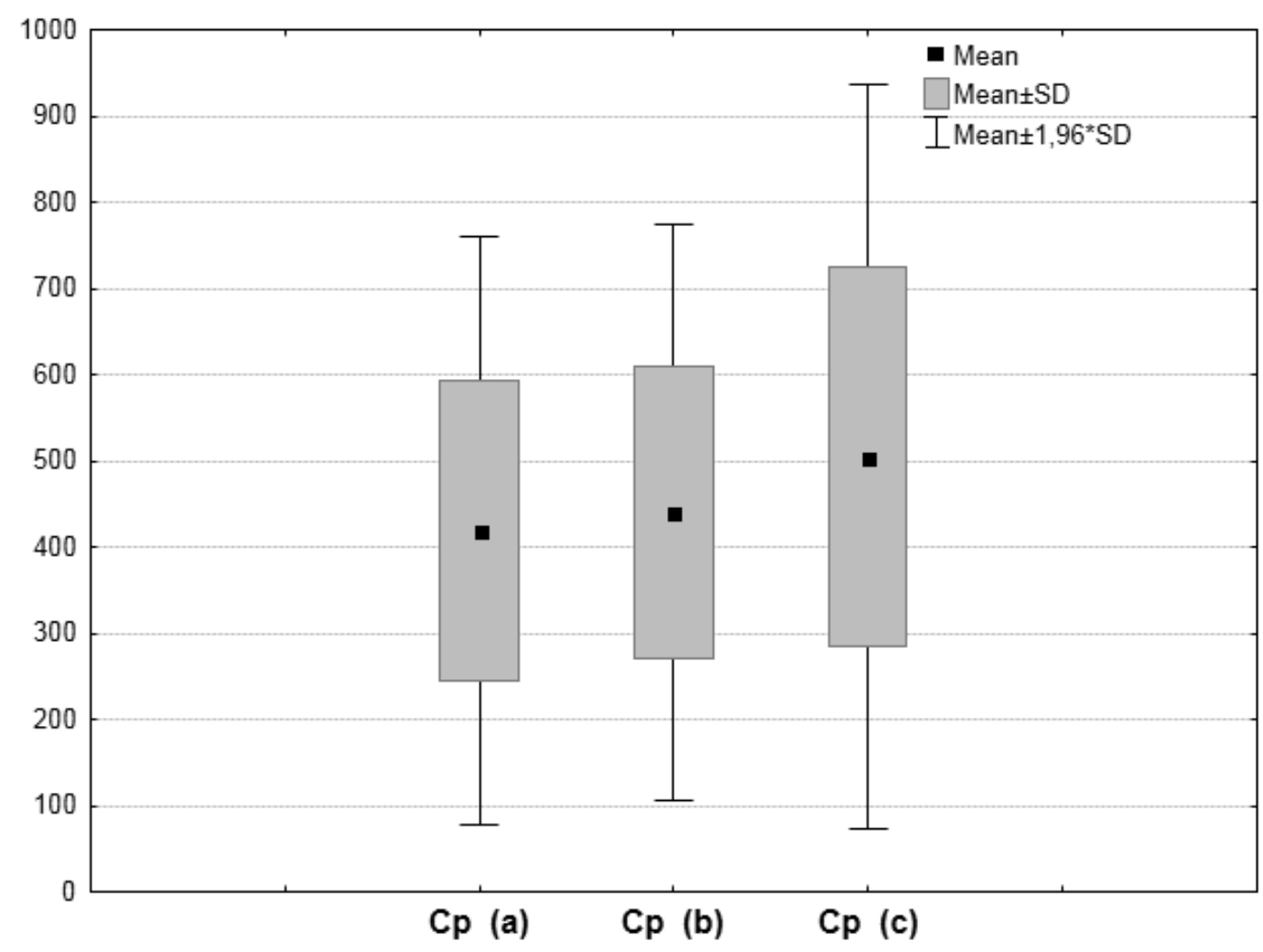

Figure 5. Cp concentrations in three consecutive measurements $(a, b, c)$ Rycina 5. Stężenia Cp z trzech kolejnych pomiarów (a, b, c) 


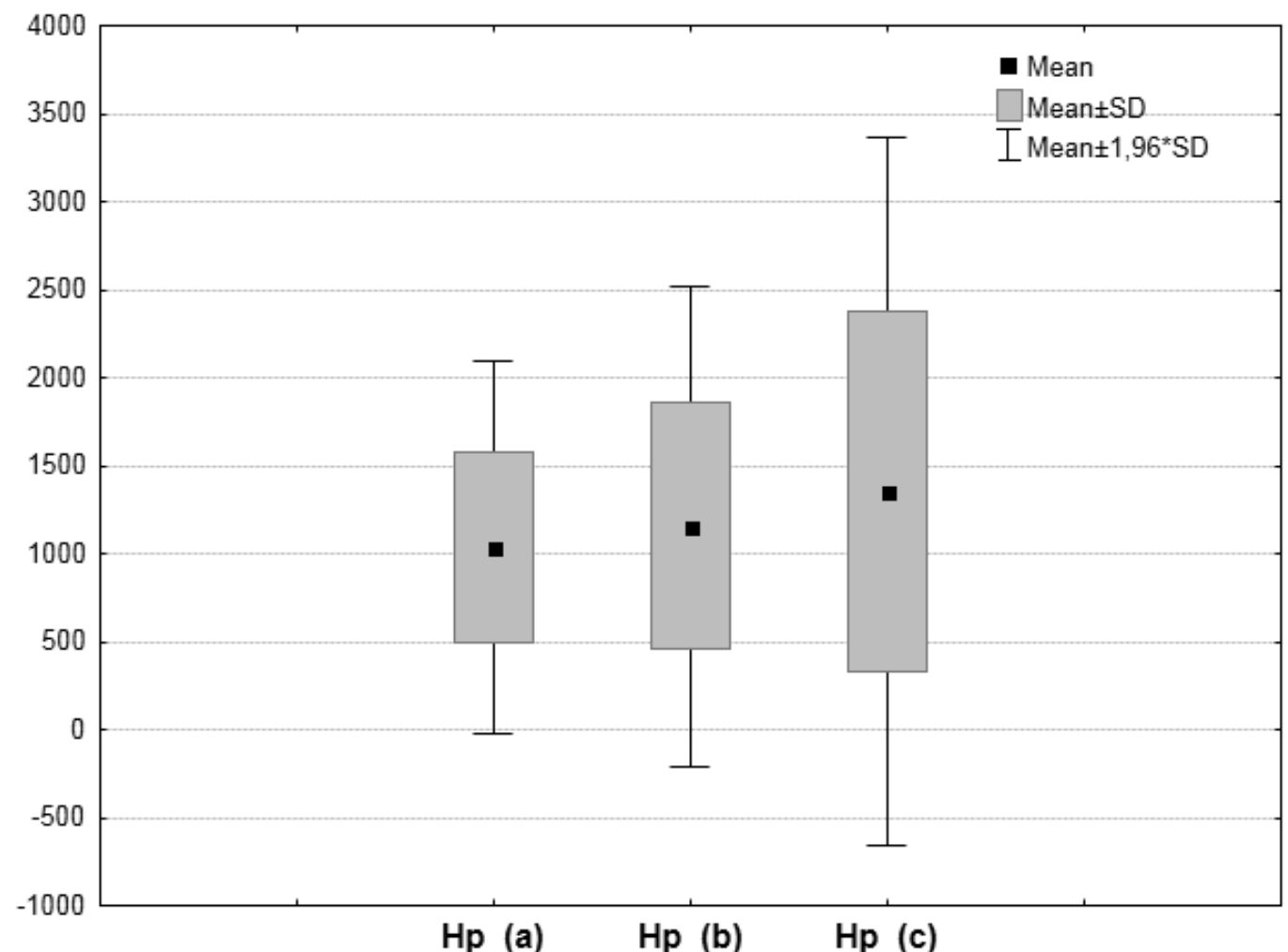

Figure 6. Hp concentrations in three consecutive measurements (a, b, c)

Rycina 6. Stężenia Hp z trzech kolejnych pomiarów (a, b, c)

one week after surgery, was statistically significant $(p<0.01)$ (Figure 5).

\subsection{Haptoglobin (Hp)}

The average concentration of haptoglobin before treatment was within the norm $(0.6-3.5 \mathrm{~g} / \mathrm{l})$ and was $1.04 \mathrm{~g} / \mathrm{l} \pm 0.5 \mathrm{~g} / \mathrm{l}$. Twenty-four hours after treatment it was $1.15 \mathrm{~g} / \mathrm{l} \pm 0.7 \mathrm{~g} / \mathrm{l}$. One week after surgery its value continued to increase up to $1.35 \mathrm{~g} / \mathrm{l}$ $\pm 0.1 \mathrm{~g} / \mathrm{l}$. The results of the second and third measurements were within the norm, too.

The increase in the average concentration of haptoglobin between the first and third measurement was statistically significant $(p<0.001)$ (Figure 6).

\section{Discussion}

The literature presents multiple reports about tooth socket augmentation performed immediately after extraction as a reasonable and effective method to preserve the volume of an alveolar bone prior to a planned implantation [28-31].

Surgical trauma and the implantation of a foreign body cause a number of physiological responses by the host organism which aims at restoring homeostasis and accelerating recovery. The bodily response to a damaging impulse is called an acute phase response wherein plasma proteins called acute phase proteins play an active role $[1,4,7,9]$. A measurable result is an increase or decrease in the blood plasma concentration of proteins. The dynamics of this increase/decrease and for restoring normative values is specific for each protein.

$\mathrm{C}$ - reactive protein belongs to a group of positive proteins, i.e. its concentration increases due to trauma or infection. The CRP protein is also a first line protein which means that its concentration begins to grow 6-8 hours after stimulation and reaches a maximum value after 24-48 hours. A decrease in CRP values is recorded after 4-5 days if the course of posttraumatic or postoperative wound healing is unremarkable or an effective treatment of the infection is implemented $[4,5,8]$. The normal CRP concentration in healthy people is $0-5 \mathrm{mg} / \mathrm{l}$. El-Hassan et al., examining the CRP concentrations after craniofacial injuries, noted a range of values from 14 to $237 \mathrm{mg} / \mathrm{l}$ [3]. Miyawaki et al. conducted a study of CRP concentrations after craniofacial surgeries and related them to the duration and extent of surgery.

They identified three study groups: the first group included procedures lasting less than four hours, such as the removal of a small cyst or a small benign tumour; the second group included procedures lasting 4-8 hours, such as the extirpation of a small malignant tumour or a large mandibular 
cyst, osteotomy or the reconstruction of the mandible. The third group consisted of procedures lasting more than 8 hours including the radical removal of malignant tumours, mainly cancers. Twenty-four hours after treatment the following average concentrations of CRP were obtained: in the first group - $3.9 \mathrm{mg} / \mathrm{l}$; in the second group - $5.6 \mathrm{mg} / \mathrm{l}$; in the third group $-8.0 \mathrm{mg} / \mathrm{l}$ [33]. In our study the average CRP concentration in patients before tooth extraction and tooth socket augmentation with the RTR bone grafting material was $0.23 \mathrm{mg} / \mathrm{l}$. Twenty-four hours after treatment the average value of CRP dropped to $0.18 \mathrm{mg} / \mathrm{l}$, and 7 days after treatment reached the highest level among the three measurements, namely 0.43 $\mathrm{mg} / \mathrm{l}$. The average concentrations of CRP from three consecutive measurements did not exceed the norm (Figure 1), but the highest single value of CRP concentration in the third measurement (43 mg/l) draws attention. The differences in the studied protein concentrations between individual measurements were not statistically significant. The CRP levels obtained in our own material seem to be consistent with surgical procedures performed as compared to the above observations by other authors.

The CRP concentration in dental implant patients as studied by Kuras showed statistically significant increases up to a value of $4.3 \mathrm{mg} / \mathrm{l}$ in the first 24 hours following the placement of two or more implants. The placing of a single implant resulted in only a slight change of CPR concentration. The author emphasised that an increase in the CPR concentration 24 hours after the procedure could indicate an acute inflammation. Still, all the measurement values were within the norm and one week later showed a tendency to decrease. Kuras also revealed that CPR concentrations after the surgical removal of third molars were similar to those following two or more implant placements. A statistically significant increase in the CPR concentration was noted 24 hours after the procedure [34]. This is confirmed in the papers by other authors [20]. Our own studies suggest that tooth extraction and tooth socket augmentation with a bone grafting material is less traumatic for the body than the placement of two or more implants or the surgical removal of a wisdom tooth.

The implantation of the RTR alloplastic material applied in the study included antibiotic cover in the form of a clindamycin formulation at a dose of $600 \mathrm{mg}$ two times daily. Comparative study by Morawiec with regard to the local and general use of gentamicin during the postoperative healing of oral wounds showed plasma CRP concentration not exceeding the upper norm limit [35].
Using the CRP level test Kim and Yoon compared tissue injuries resulting from classic and laparoscopic hysterectomies. In the former case, average postoperative CRP concentrations amounted to $39.5 \mathrm{mg} / \mathrm{l}$, and in the latter $-10.8 \mathrm{mg} / \mathrm{l}$ [36]. In orthopaedic procedures the CRP level also increased significantly above the norm on the second day after surgery $[37,38]$. Shen et al. performing arthroplasty with four different methods noted that a postoperative increase in the CRP level is not dependent on the operated area or the amount of prepared soft tissue, but on the extent of damage to the bone and bone marrow [38]. An increase in CRP values was also observed after implanting biomaterials in cardiac and gastrointestinal surgeries. Significant differences were revealed in the CRP concentrations depending on the size and type of the material used [22, 23, 26, 27].

Increased CRP values were obtained in our study from six patients, and, with one exception, the increase was noted in only one of the three measurements. The highest CRP value was observed in a female patient who developed a submucosal buccal abscess as a complication. The CRP concentration in the third measurement, taken 7 days after treatment, was $43 \mathrm{mg} / \mathrm{l}$. The significant increase in the CRP concentration correlated with a clinical picture of complications. In another patient, whose CRP concentration was $9 \mathrm{mg} / \mathrm{l}$, alveolar process resorption occurred preventing a dental implant placement. In the remaining patients increased CRP concentrations were not associated with clinical symptoms of postoperative wound inflammation. Kuras documented a similar increase in the CRP level (8-9 mg/l) in 3 cases where dental implant osseointegration had failed [20].

Transferrin belongs to a group of negative proteins, which means that its concentration decreases with a damaging stimulus. In this study, one day after surgery, a decrease in the average level of transferrin was observed comparing to the first measurement performed prior to surgery. After 7 days the protein concentration increased. All measurements were within the norm. Similar results were obtained by Kuras after placing two or more implants. Based on the presented dynamics of changes in transferrin concentration a conclusion can be drawn of rather low inflammatory activity following the treatments described above. The surgical removal of impacted wisdom teeth initiated the decreases in Tf protein concentrations both one day and one week after surgery, which proves that acute inflammation was triggered [20].

Examination of the concentrations of $\alpha 2-$ macroglobulin changes after tooth extraction and tooth socket augmentation with the RTR material 
showed the non-typical type of kinetics for this protein. Its concentration did not even reach the lower norm limit at the first measurement before surgery. The next two measurements showed increasingly lower values. L2M is a positive protein and therefore a decrease in its concentration coincides with the inflammation easing, not with its progression. An increased concentration of L2M is recorded during pregnancy, which is associated with an increased production of this protein by the placenta [3].

Evaluation of AT and $\mathrm{Hp}$ concentrations after tooth extraction and immediate implantation with RTR material revealed an increasing trend over time; however, all the measurements were within the norm. Ceruloplasmin concentration also increased, and the value of the third measurement slightly exceeded the upper norm limit. These results confirm the above mentioned proteins to be positive and second line proteins with their maximum concentration being reached $72-96$ hours after injury $[8,9]$. Differences in the concentrations oscillated within the normal range indicating a low-grade inflammation.

The results obtained of the quantitative and qualitative changes in acute phase proteins enable the conclusion to be drawn that the trauma caused by tooth removal and synthetic biomaterial implantation both show a low-grade inflammation.

It should be taken into account that the initiation of acute phase protein synthesis is primarily influenced by cytokines. However, the extent and duration of the synthesis is also affected by other factors present at the same time as well as before an acute phase reaction starts. These factors include malnutrition, vitamin $\mathrm{C}$ deficiency, chronic stress, strenuous exercise and alcohol abuse [4, 40].

The results obtained lead to the conclusion that tooth extraction along with immediate tooth socket augmentation using synthetic $\beta-$ tcp triggers a weak acute phase reaction. Therefore, higher levels of acute phase proteins, particularly CRP, could result from complications such as wound infection. This was exemplified by the distribution of the above mentioned protein concentrations in the female patient who developed a buccal abscess. In five patients, in whom resorption prevented a dental implant placement at a later date, changes in the acute phase protein concentrations were not specific enough to predict this type of complication, based on their analysis. The above conclusions, however, require further extensive research based on a much larger group of patients [41].

\section{Conclusions}

1. Tooth extraction and simultaneous implantation of the RTR bone grafting material does not adversely affect healing of the postoperative wound.

2. Despite the absence of clinical symptoms of inflammation, analysis of the concentration levels of acute phase proteins suggests a low-grade inflammation.

3. Enhancing the RTR grafting material with collagen does not affect the inflammatory process following augmentation.

4. A significant increase in CRP concentrations after purulent complications confirms the diagnostic usefulness of a concentration change analysis for this protein.

5. Changes in the concentrations of acute phase proteins cannot be a prognostic marker because their concentration in patients disqualified from implant treatment due to excessive bone resorption did not evolve in a repeatable pattern.

\section{Acknowledgements}

\section{Conflict of interest statement}

The authors declare that there is no conflict of interest in the authorship or publication of contribution.

\section{Funding sources}

There are no sources of funding to declare.

\section{References}

[1] Gołąb P, Jakóbisiak M, Zagożdżon R, Obłąkowski P. Cytokiny. In Immunologia, M Gołąb, M Jakóbisiak, W Lasek (eds). Warszawa. Wydawnictwo Naukowe PWN, 2002, pp. 198-248.

[2] Łobos M, Rusinek A, Paradowski M, Kuydowicz J, et al. Czy oznaczanie stężeń białek ostrej fazy w płynie mózgowo-rdzeniowym lub/i w surowicy w wirusowym zapaleniu opon mózgowo-rdzeniowych u dzieci ma znaczenie diagnostyczne? Część I. Limfocytarne zapalenie opon mózgowo-rdzeniowych wywołane wirusem nagminnego zapalenia przyusznic. Przegl Epidemiol. 2002;56:615-622.

[3] Wittmann K, Ciszyńska A, Sobieska M, Wiktorowicz K. Badanie stężeń i profilu glikozylacji $\alpha-2$ makroglobuliny i ceruloplazminy w przebiegu fizjologicznej ciąży. Now Lek. 1999;68(Suppl. 7):654-664.

[4] Sobieska M. Ocena przydatności oznaczania białek ostrej fazy w medycynie klinicznej. Rozprawa habilitacyjna. UM Poznań. 2008.

[5] Koj A. Biological functions of acute phase proteins. In The Acute Phase Response to Injury and Infection, AH Gordon, A Koj (eds). Amsterdam, New York, Oxford. Elsevier, 1985, pp. 145-160.

[6] Koj A. Biologiczne funkcje białek ostrej fazy. Diagn Lab. 1987;23:191-208.

[7] Koj A. Reakcja ostrej fazy i klasyfikacja białek ostrej fazy. Diagn Lab. 1985;21(Suppl. 6):261-266.

[8] Kushner I. The phenomenon of the acute phase response. Ann NY Acad Sci. 1982;389:39-48.

[9] Koj A. Definition and classification of acute phase proteins. In The Acute Phase Response to Injury and Infection, AH Gordon, A Koj (eds). Amsterdam, New York, Oxford. Elsevier, 1985, pp. 139-144.

[10] Bobilewicz D. Rola diagnostyczna białka C - reaktywnego (CRP). Przeg Med Lab. 2004;(Suppl. 1):3-4.

[11] Korczowski B, Szybist W, Romańczuk W, Sieklucki J, Rusin J. Porównanie przydatności diagnostycznej prokalcytoniny i białka $\mathrm{C}$ - reaktywnego w biegunkach o różnej 
etiologii. Pediatria Współczesna. Gastroenterologia, Hepatologia i Żywienie Dziecka. 2002;4(Suppl. 3):289-292.

[12] Muszyńska A, Steciwko A, Horst - Sikorska W, et al. Przydatność szybkich testów CRP (NycoCard IIß CRP) w codziennej pracy lekarza rodzinnego $\mathrm{w}$ aspekcie racjonalizacji wskazań do antybiotykoterapii w ostrych infekcjach. Fam Med Prim Care Rev. 2007;9(Suppl 4):998-1006.

[13] Puczko-Michalczuk A, Zoch-Zwierz W, Wasilewska A, Porowski T, Korzeniecka-Kozerska A. Ocena wskaźników zapalenia i uszkodzenia nerek u najmłodszych dzieci chorych na odmiedniczkowe zapalenie nerek. Pol Merk Lek. 2008;25:451-454.

[14] Bogdański P, Chyrek R, Pupek-Musialik D, Jabłecka A. Ocena stężenia wybranych białek ostrej fazy u chorych na zespół metaboliczny. Pol Merk Lek. 2006;121:12-14.

[15] Kasprzyk M, Dyszkiewicz W, Zwaruń D, Leśniewska K, Wiktorowicz K. Ocena wybranych białek ostrej fazy jako czynników rokowniczych u chorych leczonych chirurgicznie z powodu niedrobnokomórkowego raka płuc. Pneumol Alergol Pol. 2008;76:321-326.

[16] Pisarczyk-Wiza D, Zozulińska D, Majchrzak A, Sobieska M, Wiktorowicz K, Wierusz-Wysocka B. Ocena wybranych białek ostrej fazy u otyłych chorych na cukrzyce typu 2. Diabetol Dosw Klin. 2002;2(Supl.6):455-460.

[17] Ren FY, Malstrom HS. Rapid quantitive determination of C-reactive protein at chair side in dental emergency patients. Oral Surg Oral Med Oral Pathol Oral Radiol Endod. 2007:104:49-55.

[18] Salzberg TN, Overstreet BT, Rogers JD, Califano JV, Best AM, Schenkein HA. C-reactive protein levels in patients with aggressive periodontitis. J Periodontol. 2006;77:933-939.

[19] Adinolfi M, Lehner T. Acute phase proteins and C9 in patients with Behcet's syndrome and aphthous ulcers. Clin Exp Immunol. 1976;25:36-39.

[20] Kuras M. Ocena stanu zapalnego po niektórych zabiegach stomatologicznych na podstawie analizy wybranych białek ostrej fazy. Rozprawa doktorska. AM Poznań. 2004.

[21] Freitas AC, Pinheiro A, Miranda P, Thiers F, Vieira A. Assessment of anti-inflammatory effect of $830 \mathrm{~nm}$ laser light using C-reactive protein levels. Braz Dent J. 2001;12(Suppl. 3):187-190.

[22] Almagor $M$, Keren A, Banai S. Increased C-reactive protein level after coronary stent implantation in patients with stable coronary artery disease. Am Heart J. 2003;145:248-253.

[23] Kralisz P, Kemona H, Dobrzycki S, Bachórzewska-Gajewska H, Nowak K, Sawicki Z. Changes in C-reactive protein levels following coronary stent implantation depend on the extent of periprocedural arterial injury. Kardiol Pol. 2006;64:364-371.

[24] Markuszewski J, Wierusz-Kozłowska M, Woźniak W, Leśniewska K, Sobieska M. Odpowiedź ostrej fazy po endoplastyce stawu biodrowego i w aseptycznym obluzowaniu implantu. Chir Narzadow Ruchu Ortop Pol. 2007;72 (Suppl. 5):305-309.

[25] Markuszewski J, Wierusz-Kozłowska M, Woźniak W, Leśniewska K, Sobieska M. Charakterystyka zmian w profilu białek ostrej fazy we wczesnym okresie po endoplastyce stawu biodrowego. Ortop Traum Rehab. 2009;4:324332.

[26] Löbler M, Sas M, Kunze C, Schmitz KP, Hopt UT. Biomaterial implants induce the inflammation marker CRP at the site of implantation. J Biomed Mater Res. 2002;61:165167.

[27] Rickert D, Scheithauer MO, Coskun S, Kelch S, Lendlein A, Franke RP. The influence of a multifunctional, polymeric biomaterial on the concentration of acute phase proteins in an animal model. Clin Hemor Microcir. 2007;36:301-311.
[28] Aimetti M, Romano F, Griga F. B, Godio L. Clinical and histologic healing of human extraction sockets filled with calcium sulfate. Int $\mathrm{J}$ Oral Maxillofac Implants. 2009;24:901-909.

[29] Dominiak M, Łysiak K. Ocena skuteczności wybranej metody regeneracji kości z zastosowaniem materiału wszczepialnego w leczeniu poekstrakcyjnych ubytków kości wyrostka zębodołowego - badania wstępne. Dent Med Probl. 2006;43:368-378.

[30] Gläser R. Zastosowanie stabilnego kompozytu na bazie $\beta$-tcp dostosowującego się do kształtu ubytków kostnych. Implants. 2008;4:36-38.

[31] Irinakis T. Rationale for socket preservation after extraction of a single-rooted tooth when planning for future implant placement. JCDA. www.cda-adc.ca/jcda. 2006;12:917-922.

[32] El-Hassan BS, Peak JD, Whicher JT, Shepherd JP. Acute phase protein levels as an index of severity of physical injury. Int J Oral Maxillofac Surg. 1990;19:346-349.

[33] Miyawaki T, Maeda S, Shimada M. Elevation of plasma interleukin-6 level in patients undergoing oral and maxillofacial surgery. Oral Surg Oral Med Oral Pathol Oral Radiol Endod. 1996;81:15-20.

[34] Bulut E, Bulut S, Etikan I, Koseoglu O. The value of routine antibiotic prophylaxis in mandibular third molar surgery: acute phase protein levels as indicators of infection. J Oral Sci. 2001;43(Suppl. 2):117-122.

[35] Morawiec T. Porównanie efektów terapeutycznych miejscowego i ogólnoustrojowego podawania gentamycyny w chirurgii stomatologicznej. Czas Stomatol. 2006;59:503-509.

[36] Kim TK, Yoon JR. Comparison of the neuroendocrine and inflammatory responses after laparoscopic and abdominal hysterectomy. Korean J Anesthesiol. 2010;10:265269.

[37] Fassbender K, Gerber B, Karrer U, Sobieska M, Aeschlimann A, Muller W. Glycosylation of acute phase proteins and interleukins following hip arthroplasty: inflammation parameters studied in 10 patients. Acta Orthop Scan. 1993;64(Suppl. 2):216-220.

[38] Shen H, Zhang N, Zhang X, Ji W. C-reactive protein levels after 4 types of arthroplasty. Acta Orthop. 2009;80(Suppl. 3):330-333.

[39] Staniszewski R, Słowiński M, Leśniewska K. Ocena przydatności oznaczania białek ostrej fazy i TNF w chorobie zakrzepowo-zatorowej. Now Lek. 2005;74(Suppl. 5):564569.

[40] Krawiec A, Chrostek L, Cylwik B, Supronowicz Z, Szmitowski M. Stężenie sjalowanych glikoprotein $w$ surowicy mężczyzn uzależnionych od alkoholu. Pol Merk Lek. 2007;23:251-254.

[41] Czechowska Ewa. Ocena stężeń wybranych białek ostrej fazy po zabiegu augmentacji materiałem kościozastępczym R.T.R. Rozprawa doktorska. UM Poznań. 2012.

Acceptance for editing: 2017-09-01

Acceptance for publication: 2017-11-01

\section{Correspondence address:}

Ewa Czechowska

Poznan University of Medical Sciences

Collegium Stomatologicum

70 Bukowska Street, 60-567 Poznan, Poland

phone: +48 $618547022,+486932880$

email: eczechow@interia.pl 